\title{
Characteristic Quality of Life Children with Rheumatic Heart Disease
}

\author{
Lilis Nurhayati Sinta Marito Marpaung*, Tina Christina Lumban Tobing, Rina Amalia Caromina Saragih (D) \\ Department of Child Health, Faculty of Medicine, Universitas Sumatera Utara, Medan, Indonesia
}

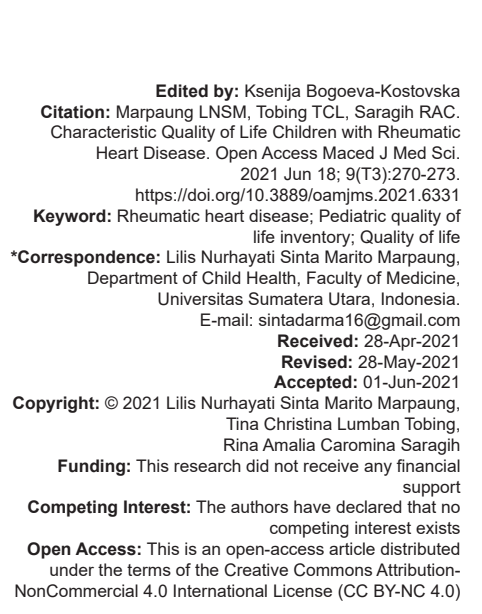

\begin{abstract}
BACKGROUND: Rheumatic heart disease is an acquired disease that has characterized damaged valve and it affects the quality of life (QoL) in children.

AIM: The aim of the study was to assess QoL in patient with rheumatic heart disease by using pediatric QoL inventory instrument at pediatric cardiologist.

METHODS: A descriptive study with cross-sectional study conduct among children aged 5-18 years old attend the Pediatric Cardiology at Haji Adam Malik Hospital Medan from 2016 to 2018.

RESULTS: A hundred children with rheumatic heart disease in this study who had affected QoL-based on group age with 5-7 year old in physical function was 6 subjects $(85.7 \%)$, social function was 1 subject $(14.2 \%)$, and school function was 2 subjects (28.5\%); group age with 8-12 year old in physical function was 100 subjects (100\%), emotional function was 3 subjects $(3 \%)$, social function was 1 subject $(3 \%)$, and school function was 5 subjects (15.1\%); group aged 13-18 years old in physical function was 60 subjects (100\%), emotional function was 1 subject $(16.7 \%)$, and school function was 51 subjects $(85 \%)$.

CONCLUSION: From 100 children with RHD dominant in the group aged 13-18 years old and male, mal malnutrition status, using of erythromycin, high senior school of level parents' education, and valve disorder was mitra regurgitation. The QoL was affected in all age groups, especially in the domain of physical function and school functions with RHD.
\end{abstract}

\section{Introduction}

Acute rheumatic fever, an inflammatory disease of the heart, develops after throat infection by Group A beta-hemolytic streptococci [1]. Rheumatic heart disease is acquired heart disease as a result of the sequel of rheumatic fever characterized by a defect in the heart valves [2]. The World Health Organization reported that 18.1 million people are living with infections caused by group A Streptococcus which is serious and causes 347,000 deaths annually with RHD [3]. The prevalence of RHD in Indonesia reported from 0.3 to 0.8 per 1000 school-aged 5-15 years old [4]. The incidence of RHD in 2017 was 72 children at Haji Adam Malik Hospital [5].

The prognosis of patients with RHD is very poor. The beginning of this chronic state usually results in devastating symptoms and physical presentations, all taking part in poor quality of life (QoL) in these patients [6]. Many factors cause increased RHD such as age, socioeconomic, nutritional status, environmental, and low awareness of disease [7]. The success of therapy is not only measured by the survival rate but also by the QoL [8]. Many factors can affect QoL in children such as medication, pain, shortness of breath, discomfort, environment, and school tasks. Declining QoL includes physical, emotional, social, and school functions. Instrument of pediatric quality of life inventory (PedsQL) can be used to assess the QoL of children with RHD.

\section{Methods}

\section{Study design}

This was a cross-sectional study by consecutive sampling. Data were obtained from medical records from 2016 to 2018 of children who diagnosed with rheumatic heart disease aged $5-18$ years old at Pediatric Cardiology at Haji Adam Malik Hospital, Medan. The exclusion criteria were children with congenital heart disease and chronic diseases. The study was approved by Research and Ethics Committee of Medical Faculty, Universitas Sumatera Utara.

\section{Instrument}

PedsQL ${ }^{\text {TM }} 4.0$ generic questionnaire consist of 4 functioning are physical (8 items), emotional (5 
items), social (5 items), and school (5 items). The questionnaire was translated into the Indonesia language. This was administered to children in the 5-7, 8-12, and 13-18 years. The instructions ask how much of a problem each item that responses are measured on a five-point rating scale which is 0 (never a problem), 1 (almost never a problem), 2 (sometimes a problem), 3 (often a problem), and 4 (almost always a problem). Each scale transformed to a score ranging from 0-100 which higher scores indicate better QoL.

\section{Statistical analysis}

Statistical analysis was performed using Statistical Package for the Social Science version 20.0. Descriptive data are used to describe the characteristics of the sample. Descriptive data are used to describe the characteristics of the sample by using univariate analysis.

\section{Results}

The general characteristics of subjects are presented in Table 1. A hundred children with rheumatic heart disease were included in this study who were 5 and 18 years old. The genders of this study are 53 male $(53 \%)$ and $47(47 \%)$ female. Children with a group aged $5-7$ years old were 7 subjects $(7 \%)$, group aged $8-12$ years old were 33 subjects (33\%), and group aged $13-18$ years old were 60 subjects $(60 \%)$. The nutritional status of children with well-nourished was 29 subjects (29\%), mild malnutrition was 46 subjects (46\%), and severe nutrition was 25 subjects (25\%). The using of antibiotic with erythromycin was 81 subjects (81\%), and penicillin was 19 subjects 919\%). Parents' education level with primary school was 20 subjects $920 \%$ ), junior high school was 28 subjects (28\%), senior high school was 45 subjects (45\%), and college was 7 subjects $(7 \%)$.

Table 1: Characteristics of study subjects $(n=100)$

\begin{tabular}{|c|c|}
\hline Characteristics & $n=100$ \\
\hline \multicolumn{2}{|l|}{ Gender, n (\%) } \\
\hline Male & $53(53)$ \\
\hline Female & $47(47)$ \\
\hline \multicolumn{2}{|l|}{ Age group, $\mathrm{n}(\%)$ (years old) } \\
\hline $5-7$ & $7(7)$ \\
\hline $8-12$ & $33(33)$ \\
\hline $13-18$ & $60(60)$ \\
\hline \multicolumn{2}{|l|}{ Nutritional status, n (\%) } \\
\hline Severe malnutrition & $25(25)$ \\
\hline Malnutrition & $46(46)$ \\
\hline Well nourish & $29(29)$ \\
\hline \multicolumn{2}{|l|}{ Antibiotic therapy, n (\%) } \\
\hline Erythromycin & $81(81)$ \\
\hline Benzathine penicillin & $19(19)$ \\
\hline \multicolumn{2}{|l|}{ Parental education, n (\%) } \\
\hline Element & $20(20)$ \\
\hline Primary height school & $28(28)$ \\
\hline Senior high school & $45(45)$ \\
\hline College & $7(7)$ \\
\hline
\end{tabular}

echocardiography with mitral regurgitation (MR) was
40 subjects (40\%), mitral stenosis was 7 subjects $(7 \%)$, aortic regurgitation was 25 subjects (25\%), tricuspid regurgitation was 18 subjects $(18 \%)$, and pulmonary regurgitation was 10 subjects $(10 \%)$ (Table 2$)$.

Table 2: Characteristics of subjects based on valve abnormalities and valve degrees according to echocardiography results

\begin{tabular}{lllll}
\hline Valve disorder & $\mathrm{n}(\%)$ & \multicolumn{3}{l}{ Degree of valve abnormality } \\
\cline { 3 - 5 } & & Mild, $\mathrm{n}(\%)$ & Moderate, $\mathrm{n}(\%)$ & Severe, $\mathrm{n}(\%)$ \\
\hline MR & $80(31.1)$ & $26(10.1)$ & $8(3,1)$ & $46(17.8)$ \\
Mitral stenosis & $17(6.6)$ & $5(1.9)$ & $2(0.7)$ & $10(3.8)$ \\
Aortic regurgitation & $64(24.9)$ & $15(5.8)$ & $21(8,1)$ & $28(10.8)$ \\
Tricuspid regurgitation & $55(21.4)$ & $34(13.2)$ & $4(1.5)$ & $17(6.6)$ \\
Pulmonary regurgitation & $41(15.9)$ & $39(15.1)$ & $1(0.3)$ & $1(0.3)$ \\
Total & $257(100)$ & $119(46.1)$ & $36(13.7)$ & $102(39.3)$ \\
\hline
\end{tabular}

The affected QoL based on group age with 5-7 year old in physical function was 6 subjects $(85.7 \%)$, social function was 1 subject $(14.2 \%)$, and school function was 2 subjects $(28.5 \%$ ) (Table 3 ); group age with 8-12 year old in physical function was 100 subjects $(100 \%)$, emotional function was 3 subjects $(3 \%)$, social function was 1 subject $(3 \%)$, and school function was 5 subjects (15.1\%) (Table 4); group aged $13-18$ years old in physical function was 60 subjects (100\%), emotional function was 1 subject $(16.7 \%)$, and school function was 51 subjects (85\%) (Table 5).

Table 3: Basic characteristics of research subjects with quality of life

\begin{tabular}{|c|c|c|}
\hline \multirow[t]{2}{*}{ Characteristics } & \multicolumn{2}{|c|}{ Quality of life value } \\
\hline & Disturbed & Undisturbed \\
\hline \multicolumn{3}{|l|}{ Gender n (\%) } \\
\hline Male & $48(48.0)$ & $5(5.0)$ \\
\hline Female & $40(40.0)$ & $7(7.0)$ \\
\hline \multicolumn{3}{|l|}{ Ages (years $\mathrm{n}[\%]$ ) } \\
\hline $5-7$ & $5(71.4)$ & $2(28.5)$ \\
\hline $8-12$ & $28(84.8)$ & $5(15.1)$ \\
\hline $13-18$ & $55(91.6)$ & $5(8.3)$ \\
\hline \multicolumn{3}{|l|}{ Nutritional status n (\%) } \\
\hline Well nourish & $8(27.5)$ & $21(72.4)$ \\
\hline Malnutrition & $33(71.7)$ & $13(45.2)$ \\
\hline Severe malnutrition & $22(88.0)$ & $3(12.0)$ \\
\hline \multicolumn{3}{|l|}{ Antibiotics n (\%) } \\
\hline Erythromycin & $62(76.5)$ & $19(23.4)$ \\
\hline Benzathine penicillin & $14(73.6)$ & $5(26.3)$ \\
\hline \multicolumn{3}{|l|}{ Parental education n (\%) } \\
\hline Elementary school & $18(90.0)$ & $2(10.0)$ \\
\hline Primary high school & $18(64.2)$ & $10(35.7)$ \\
\hline Senior high school & $39(86.6)$ & $6(44.1)$ \\
\hline College & $3(42.8)$ & $4(57.1)$ \\
\hline
\end{tabular}

\section{Discussion}

Rheumatic heart disease found persistent valve abnormalities, especially affecting the mitral and aortic valves $(25 \%)$, rarely affects the tricuspid valve and pulmonary valve [4]. Sequel and progressive valves disorder reduced productivity and QoL [9]. Researchers reported that there was no difference in gender. In this study, male was dominant with 60 children and group aged 8-12 year old. Boyarchuk et al. in Bangladesh reported 19 males (59.4\%) and 13 females (40.6\%) [10].

The incidence of infection Streptococcus occurs at the age of school children [11]. Literatures showed RHD mostly in children with group aged 5-15 years [12], [13], [14], [15]. 
Table 4: Quality of life of children of each function with rheumatic heart disease age group $5-7$ years

\begin{tabular}{lll}
\hline Characteristics & \multicolumn{2}{l}{ Quality of Life Value } \\
\cline { 2 - 3 } & Annoyed & Not disturbed \\
\hline Physical function & $7(100)$ & 0 \\
Walk more than 100 meters & $7(100)$ & 0 \\
Run & $7(100)$ & 0 \\
Physical exercise/sports & $7(100)$ & 0 \\
Lifting heavy objects & 0 & $7(100)$ \\
Bath & 0 & $7(100)$ \\
Activities around the house & 0 & $7(100)$ \\
Feeling sick & 0245 & $7(100)$ \\
Feel a little exhilarated & & \\
Emotional function & 0 & $7(100)$ \\
Feeling scared & 0 & $7(100)$ \\
Feeling sad & 0 & $7(100)$ \\
Feeling angry & 0 & $7(100)$ \\
Hard to sleep & 0 & $7(100)$ \\
Worried & & \\
Social function & 0 & $7(100)$ \\
Problems getting along with other children & 0 & $7(100)$ \\
Other kids do not want to be friends & 0 & $7(100)$ \\
Another friend taunts & 0 & $6(85.8)$ \\
Cannot do activities like friends his age & 0 & $7(100)$ \\
It is hard to make friends & $1(14.2)$ & $7(100)$ \\
School functions & 0 & $7(100)$ \\
Focus in class & 0 & $6(85.8)$ \\
Forgot some things & $1(14.2)$ & 0 \\
Doing homework & $7(100)$ & 0 \\
Missing school because she does not feel well & $7(100)$ & \\
Missed school because she went to the doctor & & \\
\hline
\end{tabular}

Rahmawaty et al. reported nutrition status with mall malnutrition was 57 children $(71.3 \%)$ children. Dominant valve disorder in children with MR followed aortic valve regurgitation due to aortic valve sclerosis which causes dilatation and hypertrophy of the left ventricle with cases of mitral valve are 1 or 3 other valves disorder [16]. In this study, dominant valve disorder was MR. Boyarchuk showed dominant valve disorder was MR in children with RHD [10]. According to Hasnul reported showed most valve disorder was MR (30.4\%) at Dr. M. Djamil Padang Hospital in 2015 [17]. Windiani et al. reported that 22 subjects with MR were 17 subjects [18].

Table 5: Quality of life for each function of children with rheumatic heart disease, age group $8-12$ years

\begin{tabular}{lll}
\hline Characteristics & \multicolumn{2}{l}{ Quality of Life Value } \\
\cline { 2 - 3 } & Annoyed & Not disturbed \\
\hline Physical function & $21(63.4)$ & $12(36.3 \%)$ \\
Walk more than $100 \mathrm{~m}$ & $33(100)$ & 0 \\
Run & $29(87.9)$ & $4(12.1)$ \\
Physical exercise/sports & $29(87.9)$ & $4(12.1)$ \\
Lifting heavy objects & 0 & $33(100)$ \\
Bath & 0 & $33(100)$ \\
Activities around the house & $9(27.2)$ & $24(72.7)$ \\
Feeling sick & $3(8.1)$ & $30(90.9)$ \\
Feel a little exhilarated & 0 & \\
Emotional function & 0 & $33(100)$ \\
Feeling scared & $11(33.4)$ & $33(100)$ \\
Feeling sad & 0 & $22(66.6)$ \\
Feeling angry & $1(3.1)$ & $33(100)$ \\
Hard to sleep & $32(96.9)$ \\
Worried & $13(39.4)$ & $20(60.6)$ \\
Social function & 0 & $33(100)$ \\
Problems getting along with other children & 0 & $33(100)$ \\
Other kids do not want to be friends & $21(63.7)$ & $12(36.3)$ \\
Another friend taunts & 0 & $33(100)$ \\
Cannot do activities like friends his age & & \\
It is hard to make friends & $28(84.9)$ & $5(15.1)$ \\
School functions & $21(63.7)$ & $12(36.3)$ \\
Focus in class & $19(57.6)$ & $14(42.4)$ \\
Forgot some things & $33(100)$ & 0 \\
Doing homework & $33(100)$ & 0 \\
Missing school because she does not feel well & & \\
Missed school because she went to the doctor & & \\
\hline
\end{tabular}

Many factors make recurrent pharyngitis, such as socioeconomic and level of education, especially in developing countries [2], [19]. Under educate of parents and income made them unknown clinical symptoms, and poor dense housing caused RHD. In this study, the highest level of parents' education with high school was 39 subjects (86.6\%). Melani, in 2009, the level of parents' education with primary school and junior school were 14 subjects (25.9\%) [20].

Table 6: Quality of life for each function of children with rheumatic heart disease, age group $13-18$ years

\begin{tabular}{lll}
\hline Characteristics & Quality value & \\
\cline { 2 - 3 } & Annoyed & Not disturbed \\
\hline Physical function & & \\
Walk more than 1 block & $54(90.0)$ & $6(10.0)$ \\
Run & $60(100)$ & 0 \\
Physical exercise/sports & $58(96.7)$ & $2(3.3)$ \\
Lifting heavy objects & $56(93.4)$ & $4(6.6)$ \\
Bath & 0 & $60(100)$ \\
Activities around the house & $46(76.7)$ & $14(23.3)$ \\
Feeling sick & $47(78.3)$ & $13(21.6)$ \\
Feel a little exhilarated & $10(16.7)$ & $50(83.3)$ \\
Emotional function & & \\
Feeling scared & $51(85.0)$ & $9(15.0)$ \\
Feeling sad & $16(26.7)$ & $44(73.3)$ \\
Feeling angry & $46(76.7)$ & $14(23.3)$ \\
Hard to sleep & 0 & $60(100)$ \\
Worried & $42(70.0)$ & $18(30.0)$ \\
Social function & & \\
Problems getting along with other children & 0 & $60(100)$ \\
Other kids do not want to be friends & 0 & $60(100)$ \\
Another friend taunts & 0 & $60(100)$ \\
Cannot do activities like friends his age & $48(80.0)$ & $12(20.0)$ \\
It is hard to make friends & 0 & $60(100)$ \\
School functions & & \\
Focus in class & $49(84.7)$ & $11(18.3)$ \\
Forgot some things & $50(83.4)$ & $10(16.6)$ \\
Doing homework & $47(78.3)$ & $13(21.6)$ \\
Missing school because she does not feel well & $59(98.4)$ & $1(1.6)$ \\
Missed school because she went to the doctor & $58(96.6)$ & $2(3.3)$ \\
\hline
\end{tabular}

Using of antibiotics give many benefits such as easy of the patient to consume compliance with prescribed regimens, price, and side effects [21]. Windiani et al. reported erythromycin treatment for 5 subjects [18]. Musoke et al. reported that children with penicillin were 82 subjects for 6 months [22]. In this study, children who consumed erythromycin were 81 subjects $(81 \%)$ and penicillin was 19 subjects (19\%). Rheumatic heart disease has affected QoL in children [23], [24], [25], [26]. Moraes et al. in Brazil reported that QoL in children with RHD such as emotional and school function was disrupted [23]. In this study, it showed affected QoL in children with group age with 5-7 year old in physical function $(85.7 \%)$, social function $(14.2 \%)$, and school function (28.5\%); group age with 8-12 year old in physical function (100\%), emotional function (3\%), social function (3\%), and school function (15.1\%); group aged $13-18$ year old in physical function $(100 \%)$, emotional function (16.7\%), and school function (85\%) (Table 6).

Limitations in this study are not using a specific questionnaire to assess the QoL of children with rheumatic heart disease and also the collection of domain questionnaires based on reports from parents or family via telephone.

\section{Conclusion}

In this study, from 100 children with RHD dominant in-group aged 13-18 years old and male, mal 
malnutrition status, using of erythromycin, high senior school of level parents' education, and valve disorder was MR. The QoL was affected in all age groups, especially in the domain of the physical function and school functions with RHD.

\section{References}

1. Helena R, Grant C, Harnden A. Acute rheumatic fever. BMJ. 2015;351:h3443. https://doi.org/10.1136/bmj.h3443 PMid:26175053

2. Siregar AA. Demam Rematik dan Penyakit Jantung Rematik: Permasalahan Indonesia. In: Pidato Pengukuhan Jabatan Guru Besar Fakultas Kedokteran USU; 2008. p. 1-38. https://doi. org/10.14238/sp14.3.2012.179-84

3. Watson G, Jallow B, Le Doare K, Pushparajah K, Anderson ST. Acute rheumatic heart fever and rheumatic heart disease in rsource limited settings. BMJ J. 2014;100(4):370-5. https://doi. org/10.1136/archdischild-2014-307938

PMid:25784737

4. Sitaresmi MN. Penilaian kualitas hidup yang berhubungan dengan kesehatan (health related quality of life). In: Lubis B, Ali M, Yanni GN, editors. Kumpulan Naskah Lengkap PIT IV IKA Medan. Medan: USU Press; 2010. p. 109-14.

5. Chakko S, Bisno AL. Acute rheumatic fever. In: Fuster V, Alexander RW, O'Rourke DK, editors. Hurst the Heart. $10^{\text {th }}$ ed. McGraw-Hill: New York; 2001. p. 1657-65.

6. Rahayuningsih SE, Farrah A. Role of echocardiography in diagnose of acute rheumatic fever. Paediatr Indones. 2010;50(2):1-9.

7. Sukman TP, Rahmat B, Najib A, Mulyadi MD, Rubiana S, Jusuf R. Profil klinis dan keluaran penyakit jantung reumatik pada anak yang menjalani bedah katup. Sari Pediatr. 2011;13(3):200-6. https://doi.org/10.14238/sp13.3.2011.200-6

8. Tambak RC. Gambaran Karakteristik Penyakit Jantung Reumatik Pada Anak di RSUP Haji Adam Malik Tahun 20017. Medan, Indonesia: Universitas Sumatera Utara; 2018. p. 1-33. https://doi.org/10.15851/jap.v4n3.901

9. World Health Organization. Rheumatic Fever and Rheumatic Heart Disease: Report of a WHO Expert Consultation. WHO Technical Report Series. Vol. 923. Geneva: World Health Organization; 2001. p. 1-65. https://doi.org/10.1016/ s0968-8080(02)00085-x

10. Monib D, Wahdan I, Hasab A, Zaher S. Health related quality of life of rheumatic heart disease patients in Alexandria: An intervention approach. Bull HIPH. 2013;43(2):112-20. https:// doi.org/10.21608/jhiph.2013.19997

11. Kushwaha N, Kamat M, Banjade B, Sah J. Prevalence of group-a streptococcal infection among school children of urban community a cross sectional study. Int J Interdiscip Multidiscip Stud. 2014;1(5):249-56.

12. Park MK. Valvular heart disease. In: Troxler RG, editor. Pediatric Cardiology for Practitioners. Maryland Heights, Missour: Mosby, Elseiver; 2002. p. 279-90.

13. Beaudoin A, Edison L, Introcaso CE, Goh L, Marrone J, Mejia A, et al. Acute rheumatic fever and rheumatic heart disease among children. MMWR Morb Mortal Wkly Rep. 2015;64(20):555-8.

\section{PMid:26020139}

14. Markowitz M. The decline of rheumatic fever: Role of medical intervention. Lews W. Wannamaker Memarial Lecture. J Pediatr. 1985;106(4):545-50.

PMid:3884760

15. Marijon E, Mirabel M. Rheumatic fever. Lancet. 2012;379(9819):953-64.

PMid:22405798

16. Bonow RO, Carabello BA, Kanu C. ACC/AHA 2006 guidelines for the management of patient with valvular heart disease: A report of the American collage of cardiology/American HEART ASSOCIATION task force in practice guidelines. Circulation. 2006;114(5):84-231. https://doi.org/10.1161/ circulationaha.106.177303

PMid: 16880336

17. Tumbel CM, Kaunang D, Rompis J. The role of parents' last education level on rheumatic heart disease in children. J Cin. 2015;1(3):585-9. https://doi.org/10.35790/ecl.3.1.2015.7655

18. Windiani AG, Vedaswari DD, Gunawijaya E, Yantie VK, Adnyana AN, Soetjiningsih. Correlation between quality of life and severity of valve abnormalities in children with rheumatic heart disease. Am J Pediatr. 2020;6(2):78-82. https://doi. org/10.11648/j.ajp.20200602.11

19. Madyono B. Epidemiologi penyakit jantung reumatik di Indonesia. J Kardiol Indones. 2005;200:25-33.

20. Melani TA. Karakteristik penderita penyakit jantung reumatik (PJR) yang dirawat inap di RSUP H. Adam Malik Medan Tahun 2004-2008. Utara: Universitas Sumatera Utara; 2009. https:// doi.org/10.15395/mkb.v49n2.1051

21. Al Qurashi M. The pattern of acute rheumatic fever in children: Experience at the children's hospital, Riyadh, Saudi Arabia. J Saudi Heart Assoc. 2009;21(4):215-20. https://doi.org/10.1016/j. jsha.2009.10.004

PMid:23960577

22. Musoke C, Mondo CK, Okello E, Zhang W, Kakande B, Nyakoojo W, et al. Benzathine penicillin adherence for secondary prophylaxis among patients affected with rheumatic heart disease attending Mulago hospital. Cardiovasc J Afr. 2013;24(4):124-9. https://doi.org/10.5830/cvja-2013-022 PMid:24217043

23. Moraes AN, Terreri MT, Hilario MO, Len CA. Health related quality of life of children with rheumatic heart disease: Reliability of the Brazilian version of the pediatric quality of life inventory ${ }^{\mathrm{TM}}$ cardiac module scale. Health Qual Life Outcomes. 2013;11:198. https://doi.org/10.1186/1477-7525-11-198 PMid:24284003

24. Cohen M, Mansoor D, Langut $H$, Lorber A. Quality of life, depressed mood, self-esteem in adolescents with heart disease. Psychosom Med. 2007;69(4):313-8. https://doi.org/10.1097/ psy.0b013e318051542c PMid:17510294

25. Allen SW, Gauvreau K, Bloom BT, Jenkins KJ. Evidence-base referral results in significantly reduced mortality after congenital heart surgery. Pediatrics. 2003;112(1 Pt 1):24-8. https://doi. org/10.1542/peds.112.1.24

PMid:12837863

26. Carapeties J, Brown A, Maguire G, Walsh W, Noonan S, Thompson $\mathrm{D}$. The Australian guideline for prevention, diagnosis and management of acute rheumatic fever and rheumatic heart disease. Menzies Sch Heart Res. 2012;30-98. 